\title{
PENGARUH VARIASI ARUS PADA PENGELASAN BAJA ST37 MENGGUNAKAN LAS SHIELD METAL ARC WELDING (SMAW) DENGAN POSISI PENGELASAN 3F
}

\section{Oktovalen Ferenza, Tuparjono, Sugiyarto}

Politeknik Manufaktur Negeri Bangka Belitung (POLMAN BABEL) Indonesia

Email: ovf131098@gmail.com, sugiyarto434@gmail.com, tuparjono@yahoo.com

\begin{abstract}
Abstrak
Pengelasan merupakan bagian yang sangat penting dalam pengembangan dan pertumbuhan industri karena memang memiliki peranan dalam rekayasa, reparasi dan konstruksi. Pengelasan SMAW (Shielded Metal Arc Welding) adalah proses penyambungan dua buah material atau lebih yang terbungkus menggunakan elektroda sebagai energi panas untuk mencairkan material tersebut. Tujuan dari penelitian ini adalah untuk mengetahui pengaruh dan cacat las yang timbul dengan variasi arus sehingga didapatkan hasil pengelasan yang optimal dari 3 amper yang diuji dengan menggunkan elektroda E6013 diameter 3,2 pada sambungan fillet posisi pengelasan $3 \mathrm{~F}$. Penelitian ini menggunakan metode eksperimental dengan bahan yang digunakan baja St 37 dengan variasi arus 90A, 100A, dan 110A. Dari penelitian yang dilakukan tidak didapatkan hasil pengelasan yang optimal dimana dari masing-masing amper yang diuji masih terjadi cacat las. Cacat yang ditimbulkan pada ketiga amper tersebut disebabkan busur, sudut elektroda, dan arc length yang melebihi batas normal dan juga dipengaruhi kecepatan pengelasan. Dari ketiga variasi amper yang digunakan didapatkan hasil pengelasan yang dominan tidak terjadi cacat las yaitu pada amper 90, sedangkan pada kaki las amper 100 menunjukan hasil kaki lasan yang baik.
\end{abstract}

Kata Kunci: arus; pengelasan smaw; baja karbon rendah; posisi pengelasan $3 \mathrm{~F}$

\section{Abstract}

Welding is a very important part in the development and growth of the industry because it has a role in engineering, repair and construction. Shielded metal arc welding (SMAW) is the process of joining two or more materials using a wrapped electrode as heat energy to melt the material. The purpose of this study was to determine the effect and welding defects that arise with current variations so that the optimal welding results obtained from 3 amperes were tested using E6013 electrode diameter 3,2 at the $3 F$ welding position fillet joint. This study uses an experimental method with the material used is St 37 steel with a current variation of 90A, 100A, and 110A. From the research conducted, it was not found optimal welding results where from each ampere tested there was still a weld defect. The defects that occur in the three amperes are caused by the arc, electrode angle, and arc length that exceed the normal limit and are also influenced by the welding speed. From the three variations of the amperage used, the dominant welding

$\begin{array}{ll}\text { How to cite: } & \text { Ferenza, O., Tuparjono, T., Sugiyarto, S. (2021) Pengaruh Variasi Arus Pada Pengelasan Baja St37 } \\ & \text { Menggunakan Las Shield Metal Arc Welding (SMAW) dengan Posisi Pengelasan 3F, Syntax Idea, } \\ & \text { 3(8), https://doi.org/10.36418/syntax-idea.v6i8.1432 } \\ \text { E-ISSN: } & \text { 2684-883X } \\ \text { Published by: } & \text { Ridwan Institute }\end{array}$


results did not occur, namely the 90 amperage, while the 100 amperage welding leg showed good results.

Keywords: flow, smaw welding; low cebon steel; $3 f$ Welding

\section{Pendahuluan}

Seiring perkembangan teknologi dibidang kontruksi, pengelasan merupakan bagian yang tak terpisakandari pertumbuhan dan perkembangan industri, karena mempunyai peran penting dalam rekayasa dan reparasi logam. Hampir setiap pembangunan melibatkan pengelasan (Parekke, Leonard, \& Muchsin, 2014).

Pengelasan merupakan teknik penyambungan logam dengan cara mencairkan dua sebagian logam, yaitu induk dan logam pengisi dengan logam penambah atau tanpa logam penambah dan akan menghasilkan logam kontinyu (Siswanto, 2011).

Pengelasan adalah ikatan karena proses metalurgi pada dua sisi sambungan logam paduan yang dilakukan dalam keadaan cair. Dari pengertian tersebut dapat diartikan bahwa sambungan dari beberapa batang logam yang mengalami proses metalurgi dengan menggunakan energi panas sebagai sumber yang dihasilkan dari panas aliran listrik ataupun api dari pembakaran gas (Mizhar \& Pandiangan, 2014). Apabila arus yang dihasilkan terlalu tinggi maka elektroda akan mencair terlalu cepat dan dapat menghasilkan permukaan las yang lebar dan penembusan yang dalam sehingga menghasilkan kekuatan tarik yang rendah dan menambah kerapuhan dari hasil pengelasan (Nastiti, Handani, \& Bandriyana, 2014).

Pengelasan yang banyak digunakan adalah pengelasan SMAW (Shield Metal Arc Welding) atau yang biaa disebut las busur listrik, Proses pengelasan smaw dilakukan dengan menggunakan energi panas listrik dengan dua polaritas AC dan DC, energi listrik diubah menjadi energi panas dengan membangkitkan busur listrik melalui elektroda (Syahrani, Naharuddin, \& Nur, 2018). Energi panas yang dihasilkan oleh lompatan ion listrik yang terjadi pada ujung elektroda dan permukaan material yang akan dilas (Achmadi, 2019).

Untuk meminimalisir terjadi cacat las tersebut dapat dilakukan dengan pemilihan arus las (ampere) pengelasan yang digunakan berdasarkan ukuran diameter elektroda (Pandapotan, 2019).

Ada beberapa penelitian yang membahas pengaruh variasi ampere telah dilakukan untuk mengetahui pengaruh pada hasil pengelasan. Penelitian tentang hasil pengelasan pada material baja lunak. Dampak cacat yang ditimbulkan dari variasi ampere yang digunakan menunjukkan bahwa hasil pengelasan yang tidak terjadi cacat las yaitu pada ampere 95 sedangkan pada kaki las ampere 115 menunjukkan hasil kaki las yang baik (Saputra, 2021). Berdasarkan hasil tersebut, pada penelitian ini akan dilakukan pengelasan dengan menggunkan variasi ampere las yang direkomendasikan dari elektroda yang digunakan. Elektroda yang digunakan dalam penelitian ini adalah AWS A5.1 E6013 dengan diameter 3,2 $\mathrm{mm}$, menggunakan posisi 3F dengan variasi ampere 90, 100 dan 110. Bahan material yang digunakan baja karbon rendah ST 37 spesifikasi setara dengan ASTM A36. 


\section{Metode Penelitian}

Metode yang digunakan dalam penelitian ini yaitu metode eksperimental untuk melihan pengaruh amper dan cacat las pada pengelasan $3 \mathrm{~F}$ yang dilakukan satu atau lebih eksperimental yang akan direkam menggunakan kamera. Untuk alur tahapan proses penelitian ditunjukkan pada diagram alur berikut ini (Gambar 1).

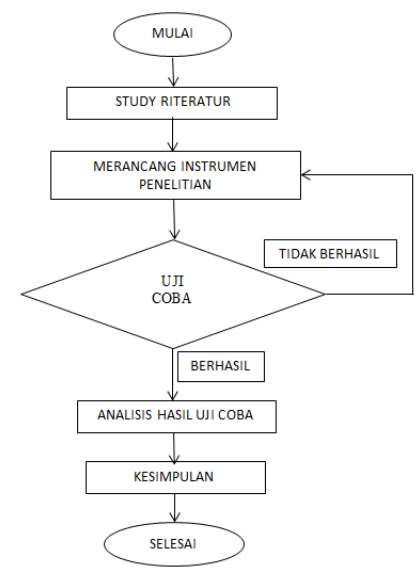

\section{Gambar 1}

\section{Diagram Alur Tahapan Proses Penelitian}

Uji coba dilakukan terhadap benda kerja dengan menggunaan ampere yang berbeda. Data uji coba penelitian yang akan dilakukan ditunjukkan pada (Tabel 1).

Tabel 1

Uji coba penelitian

\begin{tabular}{lllll}
\hline Jenis Pengelasan & Pengkutuban & $\begin{array}{l}\text { Variasi amper } \\
\text { yang digunakan }\end{array}$ & $\begin{array}{l}\text { Jumlah } \\
\text { Percobaan }\end{array}$ & $\begin{array}{l}\text { Benda } \\
\text { kerja }\end{array}$ \\
\hline SMAW (Shielded & DCRP (Direct & $90 \mathrm{~A}, 100 \mathrm{~A}, 110 \mathrm{~A}$ & $5 \mathrm{Kali}$ & Baja \\
Metal Arc & Current Revers & & percobaan & St 37 \\
Welding) & Polarity) & & $\begin{array}{l}\text { untuk masing- } \\
\text { masing amper }\end{array}$ & \\
& & & $\begin{array}{l}\text { yang } \\
\text { digunakan }\end{array}$ & \\
& & & & \\
\hline
\end{tabular}

Percobaan ini merupakan pengelasan sambungan sudut (fillet joint) posisi vertical (3F) dengan proses pengelasan SMAW (Shielded Metal Arc Welding) yang dilakukan dilaboraturium pengelasan dan pabrikasi logam Bengkel Mekanik Polman Negeri Bangka Belitung. Percobaan yang dilakukan pada penelitian ini menggunakan parameter arus pengelasan berbeda dengan 3 variasi amper yang berbeda dan masing-masing amper dilakukan sebanyak 5 (lima) kali percobaan. 
Pada uji coba ini mengguna elektroda AWS A5.1 E6013 dengan diameter 3,2 $\mathrm{mm}$, Percobaan amper yang pertama yaitu dengan arus sebesar 90A melakukan pengelasan sepanjang $90 \mathrm{~mm}$, kecepatan rata-rata pengelasan $2-4 \mathrm{~mm} / \mathrm{s}$ dengan kondisi pengelasan vertical dimana benda kerja dicekam pada tiang yang terdapat pada meja las dan awal pengelasan dimulai dari bawah ke atas. Pengamatan proses pengelasan pada busur las yang terjadi diamati dengan menggunakan sebuah kamera untuk menentukan pengamatan terhadap busur, waktu, sudut dan jarak arc length akan dijadikan sebagai sumber data pada penelitian ini. Untuk sudut elektroda dan arc length dilakukan pengukuran dengan mengambil data dari hasil rekaman dan kemudian dilakukan pengolahan dari rekaman gambar tersebut untuk melihat fenomena yang terjadi selama pengelasan (Saputra, 2021).

Percobaan arus proses pengambilan data berikutnya hampir sama hanya mengganti amper yang akan kita gunakan. Untuk lebih memperjelas skematika proses percobaan dapat dilihat pada gambar 2. Proses pengelasan dengan menggunakan perekaman dapat ditunjukkan pada (Gambar 2).

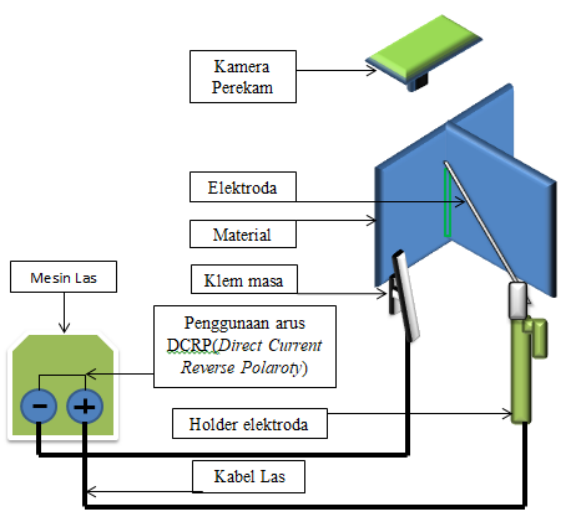

Gambar 2

Proses Pengelasan Dengan Menggunakan Perekaman

Proses pengambilan gambar pengujian visual hasil pengelasan dapat ditunjukkan pada (Gambar 3).

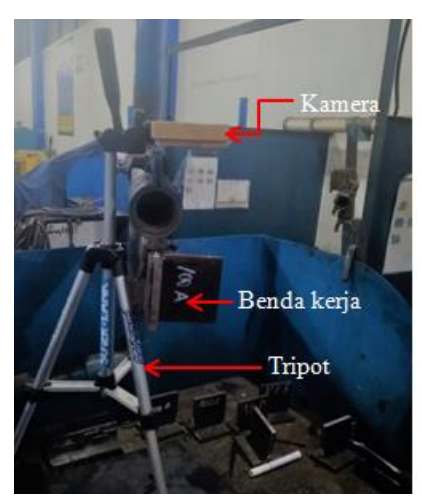

Gambar 3.

Proses Pengambilan Gambar Visual Dengan Kamera perekam. 


\section{Hasil dan Pembahasan}

1. Analisis Terhadap Nyala Busur Las Pada Ampere Yang Digunakan Yaitu 90A, 100A, Dan 110.

Pada fenomena busur las tersebut didapatkan perbedaan nyala busur yang berbeda-beda pada setiap amper yaitu 90, 100, dan 110. Pada pengamatan fenomena busur las tersebut didapatkan perbedaan nyala pada setiap sempel percobaan. Fenomena busur pada amper 90 menunjukan penyalaan busur yang tidak terlalu terang, sedangkan pada amper 100 menunjukan penyalaan busur yang lebih terang dibandingkan amper 90. Pada amper 110 nyala busur terlihat lebih besar dan terang dibandingkan dengan amper yang lainnya. Nyala busur dan lasan dapat dilihat pada gambar 4.

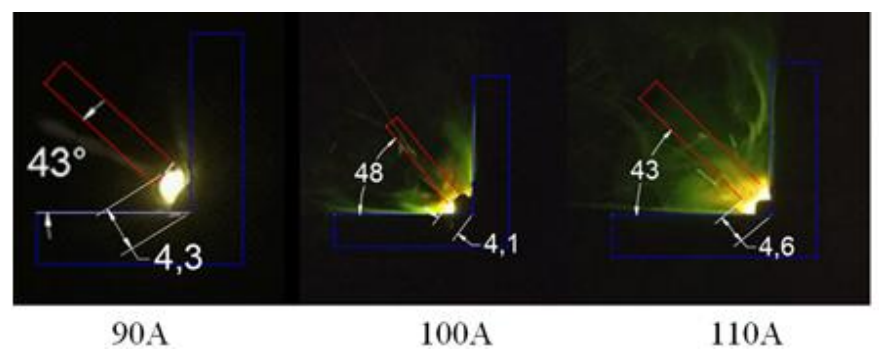

\section{Gambar 4}

Fenomena Nyala Busur Las Pada 90A, 100A, dan 110A.

Besarnya arus pengelasan yang dibutuhkan tergantung pada penggunaan diameter elektroda, tebal bahan yang dilas, jenis elektroda yang digunakan, geometri sambungan, diameter inti elektroda, posisi pengelasan (Jaemi Martins Kolo, I Nyoman Pasek Nugraha, 2017).

2. Analisis pengamatan busur las pada waktu 10 detik, 15 detik, 20 detik, dan 25 detik untuk hasil pengelasan.

Dimana pada amper 90 pergerakan busur yang tidak normal terjadi di detik 10 , dimana pergerakan sudut elektroda yang melebihi batas normal, yaitu $51^{\circ}$ dan menyebabkan terjadinya cacat lebar las yang tidak beraturan (irregular in width). Fenomena yang terjadi pada amper 90dapat dilihat pada (gambar 5). 


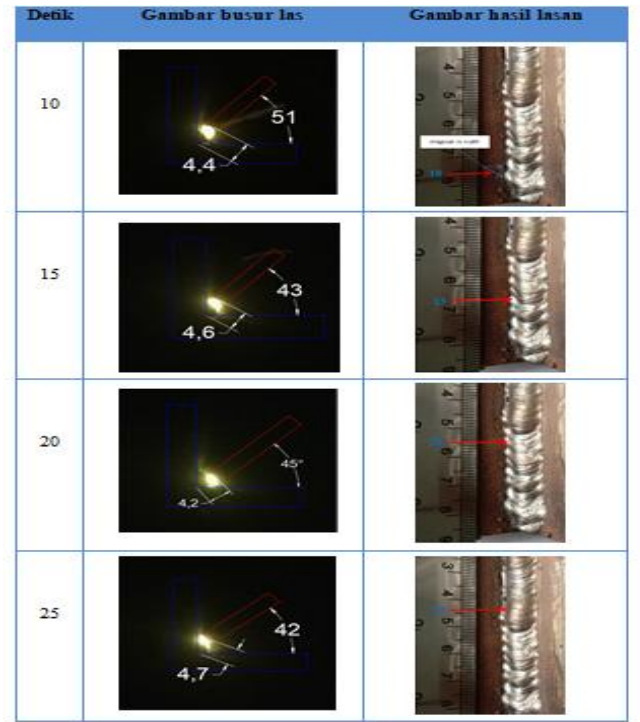

Gambar 5

Fenomena busur las amper 90 didetik 10, 15, 20, dan 25.

Sedangkan pada amper 100 fenomena pergerakan busur yang tidak normal terjadi didetik 10, 20, dan 25. Pada 10 terjadi ketidaknormalan pergerakan busur yaitu dimana jarak busur yang terlalu jauh melebihi batas normal, sehingga menyebabkan cacat dimana percikan logam las yang berlebihan (excessive spatter) dan parit-parit atau bandar di pinggir jalur las (undercut). Pada detik 20 dan 25 juga menunjukan pergerakan busur yang tidak normal, dimana jarak busur yang terlalu dekat pada benda kerja yang melebihi batas normal sehingga menyebabkan terjadinya cacat penumpukan elektroda (reinforcement). Fenomena yang terjadi pada amper 100 dapat dilihat pada (gambar 6).

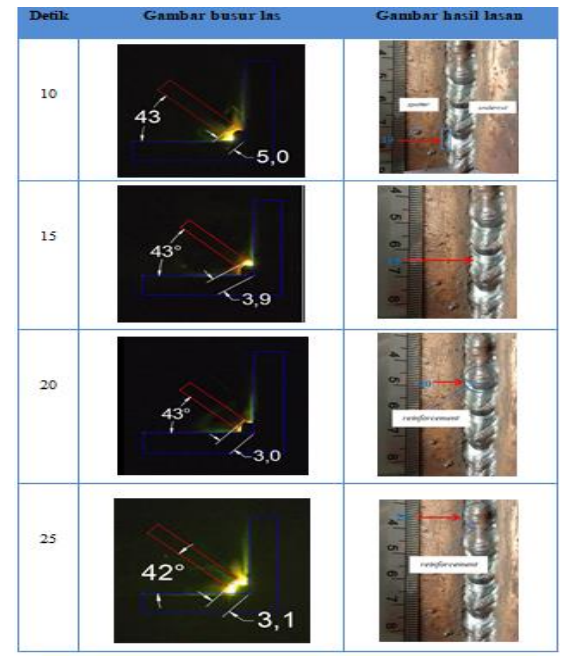

Gambar 6

Fenomena busur las amper 100 didetik 10, 15, 20, dan 25 
Pada amper 110 fenomena pergerakan busur yang kurang tepat atau tidak normal terjadi pada detik 10, 15, dan 25. Pada detik 10 terjadi ketidaknormalan pergerakan busur las, dimana sudut pengelasan melebihi batas normal, yaitu $38^{\circ}$ yang menyebabkan cacat lebar jalur las yang tidak beraturan (irregular in width). Pada detik 15 terjadi pergerakan sudut busur yang kurang tepat dan melebihi batas normal yang menyebabkan cacat parit-parit atau bandar di pinggir jalur las (undercut). Sedangkan pada detik 25 terjadi pergerakan busur yang tidak normal, dimana jarak busur yang terlalu dekat pada benda kerja yang melebihi batas normal sehingga menyebabkan terjadinya cacat penumpukan elektroda (reinforcement). Meskipun demikian cacat las yang terjadi juga dipengaruhi parameter lainnya seperti arus pengelasan yang tinggi. Fenomena yang terjadi pada amper 100 dapat dilihat pada (gambar 7).

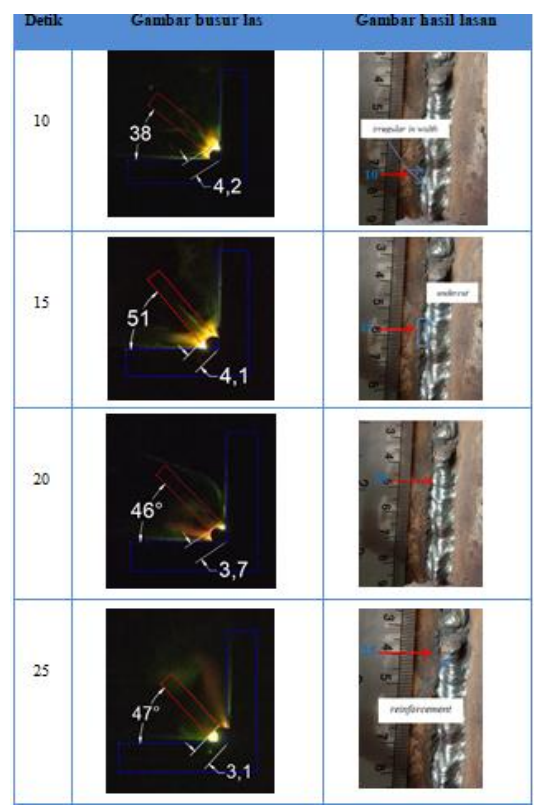

Gambar 7

Fenomena busur las amper 110 didetik 10, 15, 20, dan 25.

Hasil dari pengelasan yaitu dipengaruhi besar kecilnya aliran listrik yang keluar dari mesin las. Pemakaian amper yang akan digunakan dapat diatur pada alat mesin las. Amper pengelasan harus disesuaikan dengan jenis bahan dan diameter elektroda yang digunakan dalam proses pengelasan. Sebelum melakukan inspeksi untuk melihat adanya terjadi cacat (defect) pada hasil pengelasan perlu mengetahui ada beberapa istilah-istilah pada daerah pengelasan. Ada tiga bagian daerah pengelasan, yaitu terdiri dari logam las(an)/dasar/induk, garis peleburan (fusion line), dan HAZ (Heat Affected Zone) (American Welding Society, 2015).

Yang akan terjadi akibat dari kuat arus yang sangat rendah dapat mengakibatkan ukuran butir mengecil sehingga jarak antar butir semakin jauh, ikatan melemah, dan hasil lasan menjadi rapuh (Raharjo, 2012). Sedangkan dengan bertambahnya kuat arus pengelasan, maka akan menyebabkan ukuran butir makin membesar sehingga jaraknya 
semakin dekat dan ikatannya menguat serta kekuatan tarik dan ketangguhannya bertambah, namun masih getas (Raharjo, 2012).

Penggunaan arus atau amper yang telalu kecil akan menghasilkankan penembusan atau penetrasi las yang rendah, sedangkan penggunaan amper yang terlalu besar akan menyebabkan terjadinya manik las terlalu lebar dan deformasi dalam pengelasan (Saputra \& Syarief, 2014).

3. Pengamatan pada hasil lasan yaitu kaki las.

Penelitian yang dilakukan pada kondisi ini yaitu melihat fenomena yangterjadi pada kaki lasan dengan variasi amper yang digunakan yaitu 90A,100A,dan 110A. Pada amper 90 hasil lasan pada kaki las dapat ditunjukkan pada gambar 8 .

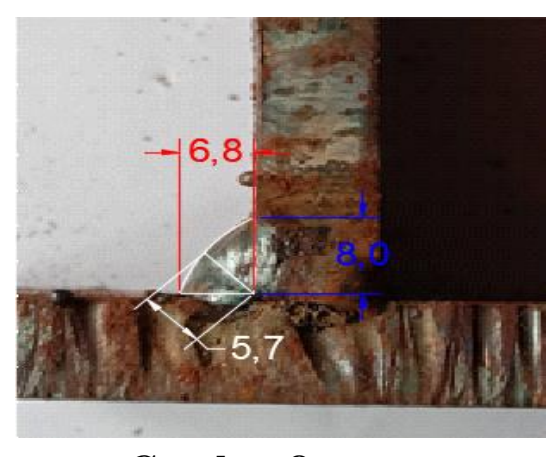

\section{Gambar 8}

Kaki lasan amper 90.

Pada amper 90 menunjukkan fenomena kaki las yang tidak semetris yaitu panjang $6,8 \mathrm{~mm}$, tinggi $8,0 \mathrm{~mm}$ dan tebal atau tebal $5,7 \mathrm{~mm}$. Kaki las yang tidak semetris disebabkan sudut elektroda yang kurang tepat dan juga dipengaruhi oleh kecepatan pada saat proses pengelasan. Kecepatan pengelasan juga berpengaruh pada daerah HAZ, kecepatan las yang semakin melambat dapat menyebabkan luasnya daerah HAZ dibandingkan kecepatan las yang semngkin cepat. Hal ini disebabkan penyebaran panas pada logam lebih lama dan juga akan mengakibatkan nilai kekerasan pada daerah HAZ akan bertambah (Mohruni \& Kembaren, 2013). Sudut pengelasan yang kurang tepat dapat dilihat pada gambar 9 .

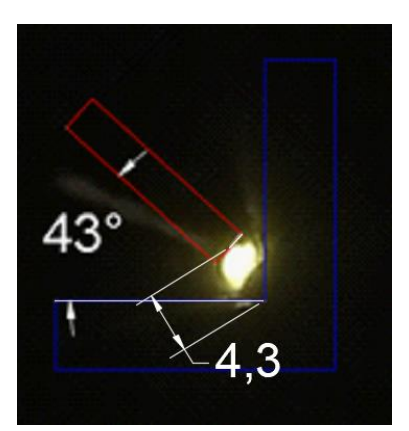

Gambar 9 


\section{Sudut pengelasan yang tidak tepat}

Pada amper 100 hasil lasan pada kaki las dapat ditunjukkan pada gambar 10.

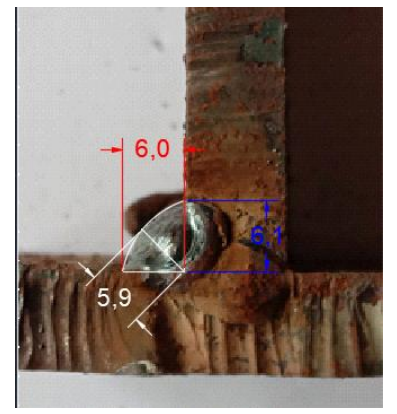

\section{Gambar 10}

Kaki lasan amper 100.

Pada amper 100 menunjukkan fenomena kaki las yang tidak semetris yaitu panjang $6,0 \mathrm{~mm}$, tinggi $6,1 \mathrm{~mm}$ dan tebal $5,9 \mathrm{~mm}$. Kaki las yang tidak semetris disebabkan sudut elektroda yang kurang tepat sedangkan ketebalan lasan yaitu disebabkan kecepatan pengelasan yang melambat. Sudut elektroda yang kurang tepat pada saat pengelasan dapat dilihat pada gambar 11.

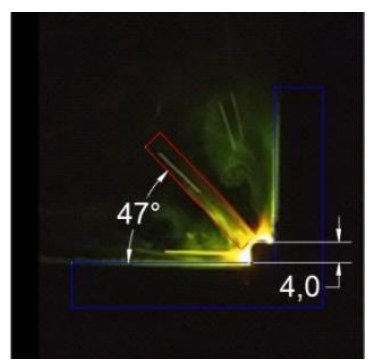

Gambar 11

Sudut pengelasan yang kurang tepat.

Pada amper 110 hasil lasan pada kaki las dapat ditunjukkan pada gambar 12.

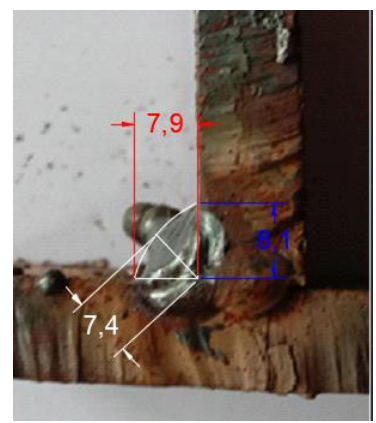

Gambar 12

Kaki lasan diamper 110. 
Pada amper 110 menunjukkan fenomena kaki las yang tidak semetris yaitu panjang 7,9 mm, tinggi $8,1 \mathrm{~mm}$ dan tebal 7,4 mm. Kaki las yang tidak semetris disebabkan sudut elektroda yang kurang tepat dan juga dipengaruhi oleh kecepatan pada saat proses pengelasan. Untuk memperjelas sudut yang kurang tepat dapat dilihat pada gambar 13.

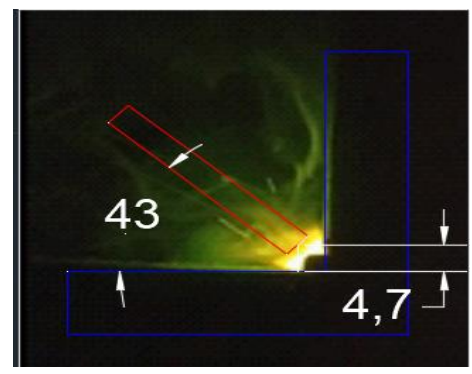

Gambar 13

\section{Sudut pengelasan yang kurang tepat.}

Dari hasil pengematan yang dilakukan pada kaki lasan didapatkan hasil kaki lasan yang tidak simetris yang diakubatkan oleh sudut pengelasan yang kurang tepat dan juga kecepatan pengelasan yang tidak tetap atau berubah-ubah, semangkin besar amper yang digunakan kecepatan pengelasan juga semangkin cepat. Kecepatan pada pengelasan juga dapat mempengaruhi hasil pengelasan termasuk kaki las, dimana pengelasan yang lambat menyebabkan kaki las yang lebar dan pengelasan yang cepat akan menghasilkan kaki lasan yang kecil (Mursid, 2009).

Sudut saat proses pengelasan, jenis elektroda, dan penggunaan arus juga mempengaruhi kekuatan tarik sambungan las (Kurniawan, Hastuti, Wibawa, \& Putro, 2018).

\section{Kesimpulan}

Bedasarkan hasil analisis data yang sudah dilakukan mengenai pengaruh amper terhadap cacat las dapat disimpulkan bahwa:

Dampak dari pengaruh variasi amper tersebut yang menunjukan paling sedikit terjadi cacat las pada amper 90 dan cacatlas lebih dominan pada amper 110. Sedangkan pada kaki lasan amper 100 mununjukan hasil kaki lasan yang baik. Dampak dari pariasi amper tersebut diidapatkan cacat las dominan terjadi pada setiap amper 100 dan 110 dibandingkan dengan amper 90 paling sedikit terjadi cacat las.

Pengamatan pada kaki lasan dari ketiga amper tersebut menunjukan hasil kaki lasan yang tidak simetris hal ini disebabkan sudut eletroda yang kurang tepat dan juga di pengaruhi kecepatan pengelasan. 
Pengaruh Variasi Arus Pada Pengelasan Baja St37 Menggunakan Las Shield Metal Arc Welding (SMAW) dengan Posisi Pengelasan 3F

\section{BIBLIOGRAFI}

Achmadi. (2019). Pengertian Las SMAW Shield Metal Arc Welding. https://www.pengelasan.net/pengertian-las-listrik-smaw-adalah/

American Welding Society. (2015). Welding Inspection Handbook, 4th edition. USA.: American Welding Society.

Jaemi Martins Kolo, I Nyoman Pasek Nugraha, Gede Widayana. (2017). Pengaruh Variasi Arus Terhadap Kekuatan Impact dan Kekerasan Material St 37 Menggunakan Proses Pengelasan Gas Tungsten Arc Welding (GTAW)". Jurnal Jurusan Pendidikan Teknik Mesin (JJPTM), 2(8), 2017.

Kurniawan, Arief Hari, Hastuti, Sri, Wibawa, Artfisco Satria, \& Putro, Hardyan Dwi. (2018). Analisa Kekuatan Sambungan Las SMAW Pada Material Baja ST 37. Jurnal Teknik Mesin MERC (Mechanical Engineering Research Collection), 1(1). Google Scholar

Mizhar, Susri, \& Pandiangan, Ivan Hamonangan. (2014). Pengaruh Masukan Panas Terhadap Struktur Mikro, Kekerasan Dan Ketangguhan Pada Pengelasan Shield Metal Arc Welding (SMAW) Dari Pipa Baja Diameter 2, 5 Inchi. Jurnal Dinamis, 2(14). Google Scholar

Mohruni, Amrifan Saladin, \& Kembaren, Billy Hizkya. (2013). Pengaruh Variasi Kecepatan Dan Kuat Arus Terhadap Kekerasan, Tegangan Tarik, Struktur Mikro Baja Karbon Rendah Dengan Elektroda E6013. Jurnal Rekayasa Mesin Universitas Sriwijaya, 13(1), 1-8. Google Scholar

Mursid, R. (2009). Pengaruh Posisi Dan Arus Las Terhadap Kecepatan Geser Pengelasan Pada Baja Lunak Dengan Menggunakan Las Busur Listrik Ac. Jurnal Penelitian Bidang Pendidikan, 1(01), 10-23. Google Scholar

Nastiti, Gemini, Handani, Sri, \& Bandriyana, Bandriyana. (2014). Pengaruh proses oksidasi pada logam paduan $\mathrm{Zr}-2,5 \mathrm{Nb}$ untuk material bioimplan. Jurnal Fisika Unand, 3(4), 205-213. Google Scholar

Pandapotan, Pasaribu Octian Putra. (2019). Pengaruh Variasi Arus dan Jenis Elektroda Terhadap Cacat Las pada Baja ST 60 Hasil Proses Pengelasan SMAW (Shiled Metal Arc Welding). Repositori usu. Google Scholar

Parekke, Simon, Leonard, Johannes, \& Muchsin, Abdul Hay. (2014). Pengaruh Pengelasan Logam Berbeda (AISI 1045) Dengan (AISI 316L) Terhadap Sifat Mekanis dan Struktur Mikro. Jurnal Sains \& Teknologi, 3(2), 191-198. Google Scholar

Raharjo, Samsudi \&. Rubijanto J. P. (2012). Variasi Arus Listrik Terhadap Sifat Mekanis Sambungan Las Shielding Metal Arc Welding (SMAW). Jurnal FT UMS, 1412-9612. 
Oktovalen Ferenza, Tuparjono, Sugiyarto

Saputra, Adhie. (2021). Pengaruh Amper Terhadap Cacat Las Pada Pengelasan Baja Lunak Dengan Menggunakan Pengelasan Smaw Posisi Pengelasan 2f. Manutech: Jurnal Teknologi Manufaktur, 13(01), 41-50. Google Scholar

Saputra, Hendi, \& Syarief, Akhmad. (2014). Analisis pengaruh media pendingin terhadap kekuatan tarik baja st37 pasca pengelasan menggunakan las listrik. Jurnal Ilmiah Teknik Mesin Unlam, 3(2), 91-98. Google Scholar

Siswanto. (2011). Konsep Dasar Teknik Las (Teori dan Praktik). Jakarta: PT Prestasi Pustakarya.

Syahrani, Awal, Naharuddin, Naharuddin, \& Nur, Muhammad. (2018). Analisis Kekuatan Tarik, Kekerasan, Dan Struktur Mikro Pada Pengelasan Smaw Stainless Steel 312 Dengan Variasi Arus Listrik. Jurnal Mekanikal, 9(1).

Copyright holder:

Oktovalen Ferenza, Tuparjo, Sugiyarto (2021)

First publication right:

Syntax Idea

This article is licensed under:

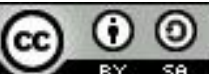

